\title{
NOTES ON THE EFFECT OF LOW TEMPERATURES UPON MILK.
}

\section{By Charles Estcourt.}

ThIs subject possesses a practical interest, inasmuch as it is not of singular occurrence to find a defence set up, founded upon such effect. The usual theory has been that cold causes all the watery portion of the milk to separate out and rise to the surface, all the soliảs of milk being left at the bottom, if the milk be exposed for a sufficiently long period.

Of course the whole theory pre-supposes no agitation of the milk by carriage, or stirring up in process of sale.

Assuming these practically impossible conditions, I obtained the following results in experiments with two milks. One milk was exposed to so low a temperature in a cylindrical vessel, about $2 \frac{1}{2}$ deep by 3 diameter, that the top, the sides, and a portion of the bottom joining the sides, were solidified to the extent of about one inch in thickness, leaving a portion liquid, which occupied part of the middle and bottom of the vessel :-

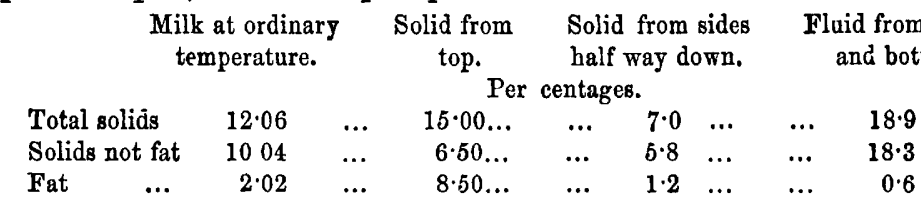

Another milk (which had been watered) was exposed to a temperature of about $38^{\circ} \mathrm{F}$ with the result that no portion of it solidified in about 12 hours.

\begin{tabular}{|c|c|c|c|c|c|c|c|c|}
\hline \multirow{3}{*}{ Total solids } & \multirow{2}{*}{\multicolumn{3}{|c|}{$\begin{array}{l}\text { Milk at ordinary } \\
\text { temperature. }\end{array}$}} & \multicolumn{2}{|c|}{$\begin{array}{l}\text { Liquid from } \\
\text { top. }\end{array}$} & \multirow[t]{2}{*}{$\begin{array}{l}\text { Liquid from } \\
\text { middle. }\end{array}$} & \multirow{2}{*}{\multicolumn{2}{|c|}{$\begin{array}{l}\text { Liquid from } \\
\text { bottom. }\end{array}$}} \\
\hline & & & & Per $\mathrm{c}$ & senta & & & \\
\hline & ... & $11 \cdot 56$ & $\ldots$ & $14 \cdot 00$ & $\ldots$ & $10 \cdot 20$ & $\ldots$ & $9 \cdot 64$ \\
\hline Solids not fat & $\ldots$ & 8.83 & $\ldots$ & 8.74 & $\ldots$ & 8.74 & $\ldots$ & $9 \cdot 03$ \\
\hline Fat ... $\quad \ldots$ & $\ldots$ & $2 \cdot 73$ & $\ldots$ & $5 \cdot 26$ & $\ldots$ & $1 \cdot 46$ & $\ldots$ & 0.61 \\
\hline
\end{tabular}

In the case with which I was concerned, the Inspector, being the first morning purchaser, was served with the top portion of the milk, and it was urged in defence that this sample appeared by analysis to have been fraudulently watered, when in fact the effect was produced by the low temperature to which the milk had been exposed.

The results of my experiments, however, disposed of this theory, for I think I may safely say no analyst would suspect watering in a milk represented by "top" in either sample. 